\title{
ANALISA TOTAL BAKTERI PADA IKAN JAPUH (Dussumieria acuta C.V.) ASAP KERING YANG ADA DI PASAR TRADISIONAL TIMINTING MANADO
}

\author{
Zakeus Awom, Helen J. Lohoo, Frans G. Ijong \\ Fakultas Perikanan dan Ilmu Kelautan, Universitas Sam Ratulangi, Manado, Sulawesi Utara.
}

\begin{abstract}
ABSTRAK
Ikan Japuh (Dussumieria acuta C.V) asap kering dan termasuk jenis ikan yang bernilai ekonomis tinggi dan biasanya dipasarkan dalam bentuk ikan Kering, Penelitian ini bertujuan untuk menganalisa Kadar air, $\mathrm{pH}$ dan TPC dan untuk mengetahui total bakteri yang terdapat pada produk ikan Japuh asap kering, yang dipasarkan di pasar Tradisional Tuminting Kota Manado. Metode penelitian yang digunakan adalah metode eksperimen. Hasil penelitian menunjukkan bahwa ikan Japuh asap kering kadar air berkisar 9,5-11\%. pH 6,03-6,18, jumlah bakteri maksimum 1,0x10 sedangkan pengujian TPC ini relatif tinggi jumlah koloninya dibandingkan dengan SNI, sehingga dapat disimpulkan bahwa ikan Japuh asap kering tidak layak dikonsumsi apabila dilakukan pemanasan atau pemasakan terlebih dahulu. Ini kemungkinan oleh aspek lingkungan dimana ikan asap kering ini dibuat bahkan dalam proses pengolahan.
\end{abstract}

Kata kunci: Ikan Japuh, Dussumieria acuta C.V, asap kering, kadar air, uji organoleptik, pasar tradisional.

\section{PENDAHULUAN}

Ikan merupakan sumber protein hewani yang nilai gizinya tinggi dan mudah diperoleh serta harganya yang relatif lebih murah dibandingkan dengan protein hewani lainnya.

Perikanan adalah suatu kegiatan ekonomi yaitu usaha manusia memanfaatkan sumber daya alam dengan cara menerapkan kaidah teknologi secara ekonomis untuk mencapai kesejahteraan manusia melalui produksi hasil perikanan. Menurut 1lyas (1983) bahwa kegiatan terbesar dari hasil perikanan yang disalurkan dalam bentuk pemasaran, segar terutama sebagai ikan basah baik yang didinginkan atau tanpa pendinginan.

Ikan merupakan komoditi yang mudah membusuk sehingga sangat sulit untuk mempertahankan kesegaran ikan sampai ke tangan konsumen (Afrianto dan Liviawaty 1989).

Prinsip penanganan ikan asap kering adalah mempertahankan kesegaran ikan dengan cara memperlakukan ikan dengan hati-hati, segera menurunkan suhu atau mendinginkan ikan sehingga mencapai suhu $0^{\circ} \mathrm{C}$ serta selalu memperhatikan waktu dan kecepatan bekerja selama rantai penanganan (llyas, 1983).

Untuk itu perlu dilakukan pengasapan untuk mempelajari cara penanganan hasil perikanan yang cepat dengan metode yang tepat agar tingkat kesegaran ikan dapat terus dipertahankan sampai ke tangan konsumen.

Penelitian ini bertujuan untuk, mengetahui penanganan ikan Japuh asap kering yang ditinjau dari tingkat pengolahannya, ikan asap kering dapat dikonsumsi dengan cara perebusan dan pemanasan.

Berdasarkan Penelitian ini diharapkan dapat memberikan informasi mengenai produk yang di nilai adalah dengan cara pengujian yaitu analisa yang dipakai sebagai alat untuk dapat menilai, mengukur, menganalisa, dan menginterprestasikan, yang timbul hasil pedagang di pasar.

Penelitian ini dilaksanakan di Laboratorium Penanganan dan Pengolahan hasil Perikanan Fakultas Perikanan dan Ilmu Kelautan Universitas Sam Ratulangi pada bulan Oktober-November 2014.

\section{METODOLOGI PENELITIAN}

Metode penelitian yang akan digunakan yaitu metode deskriptif yaitu menganalisa dan memberikan gambaran secermat mungkin mengenai suatu individu, keadaan gejala atau kelompok tertentu (Koentjorongingrat, 1989)

\section{Bahan dan Alat}

Bahan yang digunakan dalam penelitian yaitu: ikan Tandipang atau Japuh (Dussumieria 
acuta C.V) asap kering. Alat yang di gunakan untuk analisa kadar air, $\mathrm{pH}$ dan TPC yaitu: Cawan porselin, desikator, tabung reaksi, pipet, erlemeyer, autroclave, tabung Hach, blender, cawan porselen desihkator, gelaspiala dan $\mathrm{pH}$ meter.

\section{Tata Laksana Penelitian}

Dalam tata laksana kerja penelitian adapun tahapan penelitian yang akan penulis lakukan Sebagai berikut:

1. Pengambilan sampel ikan Japuh asap kering dibeli sebanyak 20 ekor di pasar tuminting. Ikan tersebut dibawa ke Laboratorium. untuk dapat pengujian $\mathrm{pH}$, TPC dan kadar air.

2. Cawan perselen, penutup di bersih, kemudian dalam oven pada suhu $105^{\circ}-$ $110^{\circ} \mathrm{C}$ selama 1 jam. Selanjutnya didinginkan dalam desikator 30 menit, dan timbangan beratnya (A) dan sampel selanjutnya diblender sampai halus, kemudian dilanjutkan dengan pengujian kadar air, $\mathrm{pH}$ dan TPC.

3. $\mathrm{pH}$ meter yang dihubungkan dengan arus listrik lalu dibiarkan sampai stabil, distadarisasi dengan larutan Buffer $\mathrm{pH} 7,0$ dan 4,0. sampel 20 gr ditambahkan $70 \mathrm{ml}$ akuades, lalu diblender selama 1 menit, kemudian dituangkan ke dalam gelas ukur 100 ml. Celupkan elektroda, dimana pencelupan beberapa saat sampai diperoleh pembacaan yang stabil dicatat nilai $\mathrm{pH}$ sampel.

\section{Analisa Statistik}

Hasil pengamatan laboratorium yang diperoleh dalam dua kategori yaitu hasil pengamatan bersifat eksploratif. Nilai pengamatan kuantitatif dilakukan perhitungan dengan nilai rata-rata, kemudian hasil perhitungan akan disajikan dalam bentuk tabel, sedangkan hasil pengamatan yang bersifat kualitatif akan disajikan dalam bentuk gambar grafik.

Analisa Kadar Air (Sudarmadji, dkk., 1989)

1. Cawan porselin dan tutupnya dicuci bersih dan kemudian dikeringkan dalam oven pada suhu $105-110^{\circ} \mathrm{C}$ selama satu jam.

2. Dengan tang penjepit cawan porselin dikeluarkan dari oven dan dimasukan dalam desikator selama 30 menit, cawan porselin yang telah dingin kemudian ditimbang (A).
3. Sampai ditimbang dengan cawan porselin tersebut sebanyak \pm 5 gram (B).

4. Cawan porselin yang berisi sampel kemudian dimasukan kembali dalam oven pada suhu $105-110^{\circ} \mathrm{C}$ selama 24 jam.

5. Kemudian cawan porselin tersebut dikeluarkan dengan tang penjepit lalu dimasukan ke dalam desikator selama 30 menit, lalu ditimbang (C).

6. Perhitungan: Kadar air $=\frac{\mathrm{B}-\mathrm{C}}{\mathrm{B}-\mathrm{A}} \times 100 \%$

\section{HASIL DAN PEMBAHASAN}

\section{Kadar Air}

Hasil analisa kadar air ikan Japuh asap kering dapat dilihat pada Tabel 1.

Tabel 1. Hasil analisa kadar air ikan Japuh (Dussuieria acuta C.V).

\begin{tabular}{cr}
\hline Sampel & Kadar air (\%) \\
\hline A1 & 9,25 \\
A2 & 9,95 \\
B1 & 11,00 \\
B2 & 9,25 \\
\hline
\end{tabular}

Analisa kadar air ikan Japuh ditentukan dengan menghitung kehilangan berat dari sampel dipanaskan, cawan perselin dan penutupnya dibersihkan kemudian dikeringkan dalam oven pada suhu $105-110^{\circ} \mathrm{C}$ selama 1 jam, selanjutnya didinginkan dalam desikator selama 30 menit, dalam timbangan beratnya (A).

Berdasarkan hasil pengujian diketahui kadar air ikan Japuh asap kering berkisar 9,5$11 \%$. Berarti ikan Japuh asap kering memiliki kadar air sesuai dengan standar mutu. Hal ini menunjukkan bahwa kombinasi proses pengasapan dan proses pengeringan ikan dapat menghasilkan produk dengan kadar air rendah.

\section{Analisa Total Bakteri Pada Ikan Japuh}

Nilai $\mathrm{pH}$ hasil analisa ikan Japuh asap kering dapat dilihat pada Tabel 2.

Tabel 2. Data hasil pengamatan nilai uji ikan Japuh asap kering.

\begin{tabular}{cc}
\hline Sampel & Total pH \\
\hline A1 & 6,03 \\
A2 & 6.18 \\
B1 & 6,12 \\
B2 & 6,09 \\
\hline
\end{tabular}

Berdasarkan data tersebut dapat dilihat bahwa nilai rata- rata $\mathrm{pH}$ yang tertinggi adalah 6,18 yang diambil dari pedagang $\mathrm{A}$, sedangkan 
pH terendah adalah 6,03 yang diambil dari pedagang A. Menurut IIyas ( 1972 ), turunnya kadar air pada ikan asap akan menyebabkan naiknya kadar asam dan adanya pengendapan berbagai senyawa kimia asap pada ikan. Hal ini dapat juga diartikan sebaliknya yaitu bila kadar air meningkat maka kadar asam dapat ikan asap akan menurun. Chamidah (2000) menyatakan bahwa selama penyimpanan terjadi penguraian protein menjadi senyawa basa berubah karena adanya protein yang terurai oleh enzim proteolitik dan bantuan bakteri terjadi asam lainnya.

\section{Analisa Total Bakteri}

Dari penelitian yang telah dilakukan terhadap ikan asap kering Japuh diambil dari pasar Tuminting Manado, maka didapatkan hasil untuk analisa total bakteri dengan menggunakan metode Total Plate Count (TPC), dilihat pada Tabel 3 .

Tabel 3. Hasil analisa total bakteri pada ikan Japuh asap kering.

\begin{tabular}{crrrr}
\hline & TPC( CFFU / GRAM ) & & \\
Sampel & $\mathbf{1 0}^{-\mathbf{1}}$ & $\mathbf{1 0}^{-\mathbf{2}}$ & $\mathbf{1 0}^{-\mathbf{3}}$ & $\mathbf{1 0}^{\mathbf{4}}$ \\
\hline A & 54 & 25 & 15 & 4 \\
A & 78 & 56 & 29 & 7 \\
B & 101 & 64 & 48 & 17 \\
B & 116 & 100 & 72 & 19 \\
\hline
\end{tabular}

Mikroba yang menyebabkan kerusakan dan berbahaya teradap keamanan produk pangan antara lain berupa bakteri. Adanya bakteri di dalam suatu produk pangan dapat ditandai oleh jumlah koloni per gram bahan makanan uji TPC. Prinsip pengujian TPC adalah Penghitungan jumlah koloni bakteri yang ada pada bahan makanan dalam suatu media yang cocok bagi pertumbuhan bakteri (Nastiti, 2006). Ada yang bersifat pathogen terhadap manusia. Untuk menjamin keamanan bahan pangan termasuk didalamnya produk olahan ikan asap, maka dilihat standar mutu, misalnya SNI yang berhubungan dengan mutu mikrobiologis seperti jumlah Total bakteri (TPC), Total Stapilokoki dan lain - lain.

\section{KESIMPULAN}

Hasil analisa kadar air pada ikan Japuh asap kering (Dussuieria acuta C.V) asap kering adalah $5,4 \times 10^{-2}-1,9 \times 10^{-5}$. Berdasarkan SNI, jumlah bakteri maksimum untuk ikan asap adalah $1,0 \times 10^{-5}$, ini berarti ikan Japuh asap kering pada sampel $A_{1}$ dan $A_{2}$ masih memenuhi syarat bakteri.

\section{DAFTAR PUSTAKA}

Buckle, K.A. R. A. Edward. G. H. Fleet, M. Wooto. 1985. Ilmu Pangan. Penerjemah Hari Purnomo dan Adiono Universitas Indonesia Jakarta.

Brehimpon, S. H. Dien, R. Montolalu, 2002. Processing and The Prospect of Kat suobushi (ikan asap kering ) of North Sulawesi, Indonesia ; A Review. Fish Handling and Processing Laboratory Faculty of Fisheries and Marine Science Sam Ratulangi University. Manado.

Fardiaz. S. A. Aprianto, S. Budianto. 1986. Penuntun Praktikum Analisa Pangan .Jurusan Teknologi Pangan dan Gizi Fakultas Teknologi Pertanian IPB. Bogor

Harikedua, J. W. 1985. Pengantar Teknologi Pengolahan Hasil Perikanan. Materi Kuliah. Perikanan dan Ilmu Kelautan. Universitas Sam Ratulangi. Manado. , 2009. Standarisasi Nasional Indonesia; Ikan Asap. Asin. Standarisasi Indonesia , 2009, Standarisasi Nasional Indonesia Ikan kayu Asin Kering Badan Standarisasi Indonesia. Jakarta.

2000. Identifikasi Dussumieria acuta (Rainbow sardine)

llyas, S. 1972. Pengantar Pengolahan Ikan Lembaga Teknologi Perikanan DIRJEN Perikanan Pengolahan dan Jakarta.

Moeljanto, 1992. Pengawetan Hasil Perikanan Penerbar Swadaya. Jakarta.

Manjoro, E. 1981. Pengantar Teknologi Penelitian. Fakultas Perikanan UNSRAT. Manado.

Saanin, H, 1984. Taksonomi dan Kunci Identifikasi Ikan. Jilid 1. Bina Cipta. Jakarta.

Soeseno, 1985. Teknik dan Penangkapan Teknologi Ikan Yasaguna. Jakarta.

Winamo, F. G. 1983. Pangan ( Gizi Teknologi dan Konsumen ) Gramedia Pustaka tama. Jakarta.

Wibowo, S. 2000. Industri Pengasapan Ikan Penerbar Swadaya Jakarta. 